\title{
PENGARUH PENGEMBANGAN KARIR DAN KOMPENSASI TERHADAP KEPUASAN KERJA KARYAWAN PT PLN (PERSERO) UID JATENG \& D.I YOGYAKARTA
}

\author{
Hanum Hotma Uli Sinaga ${ }^{1}$, Caecilia Tri Wahyanti ${ }^{2}$ \\ ${ }_{1,2}^{1,2}$ Faculty of Economics and Business \\ Universitas Kristen Satya Wacana \\ e-mail: ulisinaga.hanum@gmail.com ${ }^{1}$, caecilia.wahyanti@staff.uksw.edu²
}

\begin{abstract}
Abstrak
Pengembangan karir dan kompensasi merupakan faktor penting dalam meningkatkan kepuasan kerja karyawan. Tujuan dari penelitian ini adalah meneliti pengaruh kepuasan kerja karyawan pada PT PLN (Persero) UID Jateng \& DIY dengan data primer yang didapat dari kuesioner. Jumlah sampel yang terpilih pada penelitian ini yaitu 119 karyawan PT PLN (Persero) UID \& DIY. Teknik analisis data pada penelitian ini menggunakan teknik analisis regresi berganda dan memperoleh hasil bahwa pengembangan karir dan kompensasi berpengaruh positif terhadap kepuasan kerja karyawan. Ketika karir karyawan didalam perusahaan meningkat maka kepuasan kerja dalam dirinya akan tinggi dan hal yang sama ketika karyawan mendapatkan kompensasi yang baik dari perusahaan maka kepuasan kerja karyawan akan tinggi pula.
\end{abstract}

Kata kunci : Pengembangan Karir, Kompensasi Dan Kepuasan Kerja Karyawan

\begin{abstract}
Career development and compensation are important factors in increasing employee job satisfaction. The purpose of this study was to examine the effect of employee job satisfaction on PT PLN (Persero) UID Central Java \& DIY with primary data obtained from the questionnaire. The number of samples selected in this study was 119 employees of PT PLN (Persero) UID \& DIY. Data analysis techniques in this study used multiple regression analysis techniques and obtained results that career development and compensation had a positive effect on employee job satisfaction. When the career of an employee in a company increases, the job satisfaction will be high and the same thing when employees get good compensations from the company, employee job satisfaction will be in height as well.
\end{abstract}

Keywords : Career Development, Compensation And Employees Job Satisfaction.

\section{PENDAHULUAN}

Semakin ketatnya persaingan dalam dunia bisnis, menuntut setiap perusahaan dapat memiliki keunggulan, efisiensi, teknologi, kualitas SDM, tingkat upah, dan peluang ekspansi usaha, serta pangsa pasar komoditi yang kompetitif dan berkesinambungan, khususnya dalam perusahaan yang bergerak di bidang barang dan/atau jasa (Mulayani, 2002). Persaingan bisnis ini menuntut perusahaan untuk menyusun kembali strategi dan taktik bisnisnya. Kondisi inilah yang mendorong perusahaan-perusahaan untuk mempersiapkan diri dalam memasuki pasar global. Dengan semakin ketatnya intensitas persaingan bisnis, menjadikan perusahaan menghadapi tantangan untuk mampu

mempertahankan kelangsungan hidup. Perusahaan dituntut untuk memiliki kekuatan yang dapat bersaing dalam lingkungan yang penuh ketidakpastian (Marfokah, 2015).

Organisasi yang sukses adalah organisasi yang mampu melahirkan pemimpinpemimpin dengan komitmen kuat, memiliki visi masa depan, dan mampu menyejahterakan seluruh anggotanya (Nugroho \& Kunartinah, 2012). Keberhasilan organisasi untuk mencapai tujuan organisasi demi mewujudkan visi dan misinya sangat tergantung dari peran dan kualitas sumber daya manusia yang ada didalam organisasi tersebut. Pengembangan 
sumber daya manusia diperlukan secara terus menerus agar diperoleh sumber daya manusia yang berkualitas dan dapat mempunyai peran yang lebih, sehingga dalam bekerja dapat memberikan hasil yang optimal. Dengan sumber daya manusia yang berkualitas tentu saja akan meningkatkan produktivitas kerja dari suatu organisasi atau perusahaan. Akhyadi dan Sadikin (2015) menyatakan bahwa pengembangan sumber daya manusia merupakan suatu pembelajaran dengan tujuan untuk meningkatkan kinerja karyawan dalam menghadapi persaingan di era globalisasi. Hal ini menunjukkan bahwa pengembangan karyawan merupakan unsur penting dari berbagai upaya perusahaan untuk bersaing pada perekonomian yang baru, memenuhi tantangan persaingan global dan perubahan sosial.

Keberhasilan karyawan dalam
pengembangan karir diikuti dengan
kompensasi yang merupakan salah satu faktor yang mempengaruhi kepuasan kerja seorang karyawan. Setiap organisasi sebaiknya berupaya untuk meningkatkan kepuasan kerja karyawannya dengan memberikan kompensasi secara adil dan layak. Kompensasi memegang peranan penting dalam meningkatkan kepuasan kerja karyawan, karena salah satu alasan utama seseorang bekerja adalah untuk memenuhi kebutuhan hidupnya (Utama \& Edy,2013).

Mengacu pada penelitian sebelumnya yang dilakukan oleh Nugroho dan Kunartinah (2012) dengan membahas mengenai analisis pengaruh kompensasi dan pengembangan karier terhadap kepuasan kerja dengan mediasi motivasi kerja pada Sekretariat daerah Kabupaten Pekalongan menunjukkan bahwa Kompensasi, pengembangan karier dan motivasi kerja memiliki pengaruh positif dan siginifikan terhadap kepuasan kerja di Sekretariat daerah Kabupaten Pekalongan. Hal ini sejalan dengan penelitian yang dilakukan Kurniawan (2015) bahwa adanya pengaruh pengembangan karir dan kompensasi terhadap kepuasan kerja karyawan. Hasil analisis ini menunjukkan bahwa pengembangan karir berpengaruh terhadap kepuasan kerja karyawan dan kompensasi berpengaruh terhadap kepuasan kerja karyawan serta pengembangan karir dan kompensasi berpengaruh simultan terhadap kepuasan kerja karyawan. Penelitian ini juga didukung penelitian yang dilakukan oleh Siswadhi (2017) bahwa dari hasil penelitian menunjukan kompensasi dan pengembangan karir berpengaruh secara parsial dan simultan terhadap kepuasan kerja karyawan. Secara simultan kompensasi dan pengembangan karir berpengaruh pada kinerja karyawan. Pengembangan karir mempunyai pengaruh paling besar terhadap kepuasan kerja karyawan. Perusahaan diharapkan dapat menyesuaikan besaran bonus dan insentif dengan kinerja dari masing-masing karyawan, dapat menginformasikan serta melakukan pengembangan karir kepada para karyawan dengan baik dan lebih memperhatikan tingkat pendidikan.

Kepuasaan kerja merupakan keadaan emosional dimana para pekerja memandang pekerjaannya yang menyenangkan ataupun tidak menyenangkan. Sari \& Susilo (2018) berpendapat bahwa kepuasan kerja adalah suatu respon emosional terhadap berbagai aspek pekerjaan. Hasibuan (2006) juga menyatakan bahwa kepuasan kerja adalah sikap emosional yang menyenangkan dan mencintai pekerjaannya. Sikap tersebut dicerminkan dari moral kerja, tingkat kedisiplinan, dan prestasi dalam bekerja. Kepuasan kerja sangat penting dan bersifat relatif bagi setiap karyawan, dimana tingkat kepuasan pekerjaan berbeda-beda antara satu karyawan dengan karyawan lain. Faktor yang berpengaruh terhadap kepuasan kerja adalah pengembangan karir. Damayanti, Hanafi,\& Cahyadi (2018) menyatakan bahwa seorang pimpinan yang mengharapkan adanya kepuasan kerja yang maksimal pada organisasinya harus mengacu faktor-faktor yang dapat mempengaruhi kinerja karyawan itu sendiri, salah satunya adalah pengembangan karir (career development). Pengembangan karir adalah Aktivitas yang membantu karyawan untuk merencanakan jenjang karir masa depan mereka di perusahaan supaya perusahaan dan karyawan dapat mengembangkan diri secara maksimum. Massie, Tewal, \& Sendow (2015) menyatakan bahwa pengembangan karir merupakan pendekatan formal yang dilakukan organisasi untuk menjamin orang dalam organisasi mempunyai kualifikasi, kemampuan, dan pengalaman yang cocok ketika dibutuhkan. Pengembangan karir bertujuan untuk membantu pencapaian perusahaan, membantu menyadari kemampuan potensi karyawan, dan meningkatkan kesejahteraan karyawan. Pengembangan karir apabila diikuti dengan timbal balik perusahaan secara jelas maka dapat menimbulkan kepuasan kerja karyawan. Program pengembangan karir dijalankan dengan baik maka tingkat kepuasan kerja akan semakin tinggi. Pengembangan karir dapat menjadi faktor dominan yang mempengaruhi kepuasan kerja karyawan. 
Muchlis (2017) dalam penelitiannya menyatakan bahwa pengembangan karir merupakan suatu faktor perencanaan terorganisir yang digunakan untuk menyesuaikan tujuan karyawan dengan kebutuhan bisnis dari suatu organisasi.

Program pengembangan karir tentunya diikuti dengan faktor lain yaitu kompensasi. Firmandari (2014) mengemukakan bahwa kompensasi adalah suatu bentuk balas jasa perusahaan terhadap pengorbanan waktu, tenaga, dan pikiran yang telah karyawan berikan pada perusahaan. Kompensasi dapat dikatakan sebagai suatu timbal balik yang diterima oleh karyawan sebagai pengganti kontribusi jasa yang telah diberikan pada perusahaan. Pemberian kompensasi dari perusahaan merupakan salah satu faktor penting dan berpengaruh di dalam pemilihan untuk bekerja di sebuah organisasi (Fauzi, 2014). Kompensasi beperan penting dalam meningkatkan kepuasan kerja, karena alasan utama seorang bekerja yaitu untuk memenuhi kebutuhan hidupnya. Masalah kompensasi sangat penting karena dapat mempengaruhi semangat kerja, kegairahan kerja dan menjadikan dorongan utama bagi seseorang yang menjadi karyawan. Dengan begitu setiap perusahaan harus mempunyai strategi kompensasi yang tepat agar mencapai keberhasilan tujuan perusahaan.

Peralatan canggih dan andal yang dimiliki oleh perusahaan tidak dapat bekerja dengan baik tanpa adanya peran aktif SDM (Suwanto \& Priansa, 2011). Kinerja karyawan PLN (Perusahaan Listrik Milik Negara) sebagai BUMN (Badan Usaha Milik Negara) tentu juga dipengaruhi oleh kebutuhan tersebut. Sebagai salah satu perusahaan yang bekerja dalam menyediakan listrik dalam bentuk pembangkit listrik, PT PLN (Persero) diharuskan memiliki kinerja yang baik untuk mampu menghasilkan ketersediaan energi listrik yang cukup bagi kebutuhan masyarakat. Data yang diperoleh pada PT PLN (Persero) UID Jateng \& DIY pada Tahun 2014-2018 yang dapat dilihat pada Tabel 1 berikut ini:

Tabel 1. Pencapaian Nilai Kinerja Organisasi PT PLN (Persero) UID Jateng \& DIY Tahun 2014-2018

\begin{tabular}{ccc}
\hline No & Periode & Pencapaian Kinerja Organisasi (NKO) \\
\hline $\mathbf{1}$ & 2014 & 74,64 \\
$\mathbf{2}$ & 2015 & 90,9 \\
$\mathbf{3}$ & 2016 & 39,6 \\
$\mathbf{4}$ & 2017 & 90,2 \\
$\mathbf{5}$ & 2018 & 95,7 \\
\hline
\end{tabular}

Sumber: PT PLN (Persero) UID Jateng \& DIY Pada Tabel 1 terlihat bahwa kinerja karyawan PT PLN (Persero) UID Jateng \& DIY masih perlu dioptimalkan karena pencapaian kinerja organisasi (NKO) mengalami fluktuasi yaitu dari 74,64 pada tahun 2014 mengalami kenaikan menjadi 90,9 pada tahun 2016. Namun pada tahun 2017 mengalami penurunan yang sangat signifikan yaitu menjadi sebesar 39,6. Pada tahun 2017 dan 2018 mengalami kenaikan dengan sangat pesat menjadi 90,2 dan 95,7. Data yang diperoleh dari PT PLN (Persero) UID Jateng \& DIY mengenai kinerja karyawan PT PLN (Persero) UID Jateng \& DIY yang masih harus dioptimalkan menarik minat peneliti untuk melakukan penelitian dengan obyek penelitian pada BUMN yaitu PT PLN (Persero) UID Jateng \& DIY yang berlokasi di Semarang.

Berdasarkan hasil pra penelitian yang dilakukan pada Kantor PT PLN (Persero) UID Jateng \& DIY mengenai pengembangan karir pada PT PLN (Persero) UID Jateng \& DIY yang memiliki program dalam menunjang karir para karyawan, tetapi terdapat beberapa

permasalahan yang muncul mengenai pengembangan karir dan kompensasi yang dirasa masih belum optimal. Terdapat perbedaan gaji yang diterima oleh masingmasing karyawan di PT PLN (Persero) UID Jateng \& DIY membuat munculnya masalah kepuasan terhadap kinerja karyawan tersebut. Karyawan tidak tetap di PT PLN (Persero) UID Jateng \& DIY hanya menerima $1 / 3$ dari gaji yang diterima oleh karyawan tetap disana, mereka menganggap ini sebagai ketidakadilan karena jika dilihat dari segi kinerja dan pekerjaan mereka tidak kalah dengan karyawan tetap dan justru ada karyawan tidak tetap yang masa kerjanya 10-20 tahun yang dapat menjadikan mereka kunci ketika berada dilapangan dan adanya penyebaran informasi mengenai ketersediaan posisi dan data yang lengkap mengenai syarat untuk menempati suatu jabatan tertentu belum dilakukan secara transparan dan masih terdapat pengaruh 
koneksi untuk meningkatkan karir dan tidak mensyaratakan jenjang pendidikan untuk dipromosikan pada jabatan tertentu. Kegiatan promosi pada pengembangan karir pada PT PLN (Persero) UID Jateng \& DIY tidak dilakukan dengan berkala melainkan tergantung dari nilai perolehan kerja karyawan. Jika terdapat 10 kandidat yang memiliki potensi namun hanya 5 yang diajukan berdasarkan riwayat kinerja masing-masing karyawan. Maka dari itu penelitian ini akan menganalisa seberapa besar pengembangan karir berpengaruh terhadap kepuasan kerja karyawan dan seberapa besar kompensasi berpengaruh terhadap kepuasan kerja karyawan.

Adapun persoalan penelitian yang akan dibahas dalam dua pertanyaan yaitu pertama, apakah pengembangan karir berpengaruh terhadap kepuasan kerja karyawan dengan kompensasi? Kedua, apakah variabel kompensasi berpengaruh terhadap kepuasan kerja karyawan?

Tujuan yang ingin dicapai dalam penelitian ini adalah untuk menganalisis seberapa besarnya pengaruh dari pengembangan karir terhadap kepuasan kerja para karyawan dari PT PLN (Persero) UID Jateng \& DIY. Penelitian ini juga memiliki tujuan untuk menganalisis seberapa besar pengaruh kompensasi terhadap kepuasan kerja karyawan pada PT PLN (Persero) UID Jateng \& DIY dan menganalisis mengenai pengaruh hubungan antara pengembangan karir dan kompensasi. Penelitian ini diharapkan dapat bermanfaat bagi karyawan dalam menambah wawasan dan pengetahuan mengenai Sumber Daya Manusia khusunya mengacu pada kepuasan dari kinerja karyawan, pengembangan karir dan kompensasi. Terdapat pula manfaat bagi pembaca dan penulis yakni diharapkan dapat diguakan sebagai literature refrensi pada penelitian selanjutnya. Penelitian ini juga dapat digunakan untuk umpan balik kepada PT PLN Semarang sebagai kajian atau bahan dalam menentukan kebijaksanaan SDM perusahaan tersebut.

Paramita, Wahda, \& Handaru (2015) berpendapat bahwa pengertian karir adalah rangkaian posisi yang berkaitan dengan kerja yang ditempati seseorang sepanjang hidupnya. Alif (2015) karir adalah proses kemampuan kerja individu yang dicapai baik secara fungsional ataupun struktural sesuai yang diinginkan. Sugiharjo \& Rustinah (2017) karir adalah sejumlah posisi kerja yang dijabat seseorang selama siklus kehidupan pekerjaan sejak dari posisi paling bawah hingga posisi paling atas. Permatasari (2006). karier adalah persepsi sikap pribadi dan perilaku seseorang yang terkait dengan aktivitas-aktivitas dan pengalaman-pengalaman dalam rentang perjalanan pekerjaan seseorang.

Alif (2015) menyatakan bahwa pengembangan karir dapat diartikan sebagai proses peningkatan kemampuan kerja individu yang dicapai dalam rangka mencapai karir yang diinginkan. Hal ini didukung oleh Putra, Musnadi, dan Majid (2014) bahwa pengembangan karir yaitu perkembangan karyawan secara individu dalam kepangkatan atau jenjang jabatan yang ingin dicapai selama bekerja dalam perusahaan yang bersangkutan.

Berdasarkan beberapa definisi yang telah diungkapkan diatas dapat disimpulkan bahwa pengembangan karir merupakan suatu proses yang dilakukan pada suatu organisasi dalam rangka melakukan perubahan status, posisi, atau kepangkatan dan peningkatan kemampuan seseorang sebagai pelaku yang terlibat dalam kegiatan organisasi tersebut

Kompensasi adalah bentuk pembayaran yang diberikan organisasi kepada karyawan sebagai pertukaran pekerja yang telah mereka berikan kepada organisasi. (Suwanto \& Priansa, 2011). Kompensasi merupakan imbalan balas jasa yang berbentuk barang tidak langsung, barang langsung ataupun uang dari perusahaan yang diterima kepada karyawan (Hasibuan, 2012). Kompensasi adalah komponen penting pada karyawan sebagai balas jasa berupa pembayaran tunai , pembayaran tidak langsung untuk memotivati karyawan supaya bekerja keras (Sunyoto, 2012). Berdasarkan penjelasan definisi diatas dapat disimpulkan bahwa kompensasi adalah imbalan jasa dari perusahaan yang diberikan kepada karyawan atas hasil kinerja sebagai pertukaran pekerja yang dapat berbentuk barang tidak langsung dan barang langsung.

Noe dan Mondy (2005) menyatakan bahwa indikator kompensasi finansial terbagi menjadi tiga, yaitu:

1. Upah dan gaji

Imbalan finansial yang dibayarkan kepada karyawan secara teratur seperti tahunan, caturwulan, bulanan dan mingguan.

2. Insentif

Insentif merupakan imbalan langsung yang dibayarkan kepada karyawan karena kinerjanya melebihi standar yang ditentukan. Dengan mengasumsikan bahwa uang dapat digunakan untuk mendorong karyawan bekerja lebih giat lagi maka mereka yang produktif lebih 
menyukai gajinya dibayarkan berdasarkan hasil kerja.

3. Tunjangan

Imbalan tidak langsung yang diberikan kepada karyawan, biasanya mencakup asuransi kesehatan, cuti, pensiun, rencana pendidikan, dan rabat untuk produk-produk perusahaan.

Kepuasan kerja adalah menggambarkan seseorang atas perasaa sikapnya, puas atau tidak puas, senang atau pun tidak senang di dalam bekerja (Paramita, Wahda, \& Handaru, 2015). Hal senada juga diungkapkan oleh Supatmi, Nimran, \& Utami (2011) mengatakan bahwa kepuasan kerja adalah perasaan karyawan yang menyenangkan ataupun tidak menyenangkan terhadap pekerajaan, tingkah laku dalam bekerja seperti kinerja karyawan dan secara langsung yang berpengaruh terhadap emosional.

Luthans (2006) menyatakan bahwa indikator yang dapat digunakan dalam mengukur kepuasan kerja adalah sebagai berikut: a) kepuasan terhadap pekerjaan itu sendiri, b) kepuasan terhadap gaji, c) kepuasan dengan promosi, d) kepuasan terhadap atasan, e) kepuasan terhadap rekan kerja.

Beberapa penjelasan definisi diatas dapat disimpulkan bahwa kepuasan kerja yaitu penggambaran seseorang terhadap pekerjaan dari segi perasaan menyenangkan atau tidak menyenangkan, puas atau tidak puas dalam kinerja karyawan tersebut.

Dessler (2006) mengemukakan bahwa adanya pengembangan karir dan perencanaan, keuntungan yang jelas bagi karyawan yaitu kepuasan, kualitas kerja yang baik dan pengembangan diri. Dengan adanya pengembangan karir yang baik maka akan menciptakan kepuasan dalam melaksanakan pekerjaannya. Dalam penelitian Lisdiani (2017) menyatakan bahwa pengembangan karir berpengaruh positif dan signifikan terhadap kepuasan kerja. Sehingga ketika karyawan diberikan kesempatan untuk mengembangkan karir maka kepuasan kerja karyawan akan terpenuhi. Penelitian tersebut diperkuat penelitian dari Siswadhi (2017) bahwa pengembangan karir berpengaruh positif dan signifikan terhadap kepuasan kerja.

H1 Pengembangan karir berpengaruh positif : $\quad$ terhadap kepuasan kerja karyawan PT PLN (Persero) UID Jateng \& DIY

Kompensasi adalah segala sesuatu yang diterima para karyawan sebagai balas jasa untuk kerja mereka (Handoko, 2012). Kompensasi merupakan hal yang sangat penting bagi karyawan untuk memenuhi kebutuhan sehari-hari maupun bersama keluarganya. Kompensasi yang diberikan oleh perusahaan kepada karyawan dapat mempengaruhi banyak hal, salah satunya yaitu kepuasan kerja. Penelitian terdahulu oleh Akmal \& Tamini (2015) menyatakan bahwa kompensasi berpengaruh positif dan signifikan terhadap kepuasan kerja karyawan yang artinya ketika kompensasi yang diberikan semakin besar maka kepuasan kerja karyawan menjadi lebih baik. Pernyataan tersebut diperkuat penelitian dari Humaeroh, Susilo, \& Prasetya (2015) serta Retnoningsih, Sunuharjo, \& Ruhana (2016) yang menyatakan bahwa kompensasi finansial dan non finansial berpengaruh positif dan signifikan terhadap kepuasan kerja karyawan.

H2 Kompensasi berpengaruh positif : $\quad$ terhadap kepuasan kerja karyawan pada PT PLN (Persero) UID Jateng \& DIY

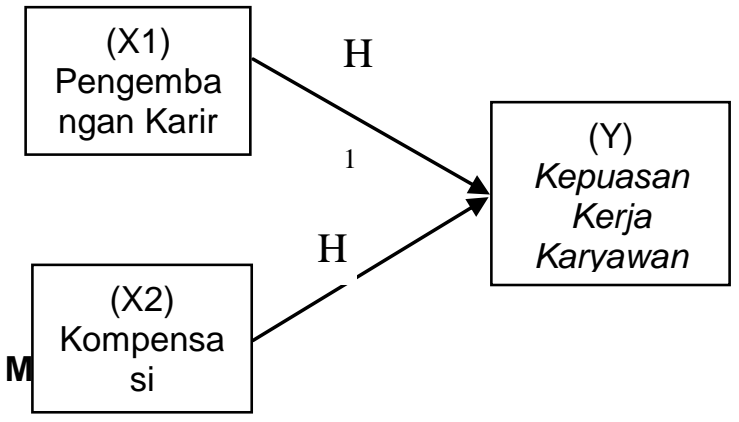

Gambar 1. Pengaruh Pengembangan Karir dan Kompensasai Terhadap Kepuasan Kerja Karyawan

\section{METODE}

Penelitian ini menggunakan pendekatan kuantitatif, dimana tujuan dan objek penelitian ini dilakukan dengan penelitian kausalitas (causality research). Penelitian kausalitas bertujuan untuk menyelidiki adanya hubungan sebab akibat dari peristiwa fenomena. Jenis penelitian kausalitas ini mengambil dari penelitian penjelasan (explanatory research) yakni kausalitas menjelaskan suatu hubungan kausalitas dengan cara mendasarkan pada pengamatan terhadap akibat yang terjadi, dan mencari faktor - faktor yang mungkin menjadi penyebabnya melalui data tertentu. Dipilinnya jenis penelitian ini untuk menjelaskan hubungan dan pengaruh yang terjadi antar kuesioner sebagai alat pengumpul data primer Priyatno (2013).

Populasi penelitian ini adalah SDM pada perusahaan PT PLN (Persero) UID Jateng \& DIY. Terdapat 169 jumlah karyawan 
yang ada di PT PLN (Persero) UID Jateng \& DIY. Penelitian ini menggunakan teknik pengambilan sampel dengan metode purposive sampling dengan kriteria sampelnya yaitu: a) karyawan tetap PT PLN (Persero) UID Jateng \& DIY; b) Karyawan memiliki jabatan pada perusahaan. Pradana \& Reventiary (2016) menggunakan perhitungan rumus sampel dengan rumus Slovin sebagai berikut:

$\mathrm{n}=\frac{\mathrm{N}}{1+N e^{2}}$

$$
\begin{aligned}
& \mathrm{n}=\frac{\mathrm{N}}{1+N e^{2}} \\
& \mathrm{~N}=\frac{169}{1+\left(169 \times 0.05^{2}\right)} \\
& \mathrm{N}=119
\end{aligned}
$$

Keterangan :

$\mathrm{n}$ : Jumlah sampel

$\mathrm{N}$ : Jumlah populasi

e : Tingkat kesalahan pengambilan sampel yang dapat ditolerir

Tabel 2. Sampel per Bidang

\begin{tabular}{lllll}
\hline No & Bidang & Populasi (orang) & Proporsi Sampel & Jumlah Sampel \\
\hline 1. & Pengadaan & 8 & $8 / 169 \times 119$ & 6 \\
2. & Perencanaan & 11 & $11 / 169 \times 119$ & 8 \\
3. & Distribusi & 28 & $28 / 169 \times 119$ & 20 \\
4. General Affairs & 26 & $26 / 169 \times 119$ & 20 \\
5. Keuangan & 29 & $29 / 169 \times 119$ & 21 \\
6. & Niaga & 30 & $30 / 169 \times 119$ & 22 \\
7. SDM & GM (General Manager) & 1 & $22 / 169 \times 119$ & 16 \\
8. & K3L & 6 & $1 / 169 \times 119$ & 1 \\
9. & 169 & $6 / 169 \times 119$ & 5 \\
Jumlah & & & 119 \\
\hline
\end{tabular}

Berdasarkan perhitungan diatas didapatkan sampel sebesar 119 responden. Sampel sendiri akan dibagi kedalam beberapa divisi sesuai tabel diatas.

Metode yang digunakan pada penelitian ini adalah metode survey yang bertujuan untuk mengumpulkan data sederhana dalam rangka menguji hubungan antar variabel (Sugiyono 2013). Metode pengumpulan data pada penelitian ini menggunakan kuesioner yakni dengan cara memberi seperangkat pertanyaan atau pernyataan tertulis kepada responden untuk dijawabnya. Variabel terikat pada penelitian ini yaitu kepuasan kerja karyawan, sedangkan variabel bebas kompensasi dan pengembangan karir Penelitian ini

\begin{tabular}{|c|c|c|}
\hline Variabel dan Definisi & Dimensi & Indikator \\
\hline $\begin{array}{l}\text { Pengembangan } \\
\text { merupakan suatu proses } \\
\text { peningkatan/perkembangan } \\
\text { karyawan secara individu } \\
\text { dalam rangka mencapai karir } \\
\text { yang diinginkannya. } \\
\text { (Handoko, 2008). }\end{array}$ & $\begin{array}{l}\text { a) Pendidikan } \\
\text { b) Pelatihan } \\
\text { c) Pengalaman Kerja } \\
\text { (Handoko, 2008) }\end{array}$ & $\begin{array}{l}\text { - } \quad \text { Latar belakang pendidikan } \\
\text { karyawan. } \\
\text { - Wawasan pengetahuan yang } \\
\text { dimiliki karyawan. } \\
\text { - } \quad \text { Frekuesi pelatihan yang } \\
\text { diberikan perusahaan kepada } \\
\text { karyawan. } \\
\text { Keahlian tertentu yang dimiliki } \\
\text { karyawan. } \\
\text { - } \quad \text { Masa kerja karyawan dalam } \\
\text { melaksanakan tugasnya. } \\
\text { Tingkat penguasaan karyawan } \\
\text { atas pengetahuan yang dimiliki. } \\
\text { Tingkat ketrampilan karyawan } \\
\text { dalam melakukan pekerjaan. }\end{array}$ \\
\hline
\end{tabular}
menggunakan skala likert untuk menjawab pertanyaan yang diajukan ke responden

Tabel 3. Operasional Variabel Penelitian 


\begin{tabular}{ll}
\hline Variabel dan Definisi & Dimensi \\
\hline &
\end{tabular}

(Noe \& Mondy, 2005)

Kepuasan kerja merupakan perasaan karyawan yang dapat digambarkan sebagai tingkah laku dalam bekerja seperti kinerja karyawan yang secara langsung dapat berpengaruh terhadap emosional karyawan ketika mereka bekerja.

(Robbins, 2013).

b) Gaji

c) Lingkungan kerja

\author{
Indikator
}

- Jumlah gaji diterima memenuhi kebutuhan hidup.

- Jumlah gaji yang diterima meningkatkan semangat kerja.

- Jumlah gaji diterima sesuai ketetuan yang ditetapkan.

- Pemberian insentif untuk meningkatkan motivasi.

- Pemberian tunjangan profesi secara rutin.

- Pemberian tunjangan sesuai aturan yang berlaku.

- Pemberian tunjangan dalam meningkatkan semangat kerja.

(Noe \& Mondy, 2005)

a) Pekerjaan itu sendiri - Tingkat pekerjaan sesuai kemampuan.

(Robbins, 2013).
- Tingkat pekerjaan yang secara mental menantang.

- Tingkat kepuasan terhadap gaji yang diterima.

- Tingkat kepuasan terhadap kecepatan pembayaran gaji.

- Keefektifan pemberian motivasi dari manajer untuk meningkatkan semangat kerja.

- Keberadaan rekan pekerjaan yang dapat meningkatkan semangat kerja.

- Keefektifan lingkungan pekerjaan dalam memberikan kenyamanan saat bekerja.
Teknik analisis data menggunakan analisis regresi berganda. Sebelumnya perlu melakukan analisis statistik deskriptif dan juga data yang telah diperoleh diuji terlebih dahulu dengan uji kualitas instrumen yakni dengan uji realibilitas dan validitas, kemudian dilanjutkan dengan pengujian asumsi klasik untuk datadata variabel yang terhimpun, yaitu pengujian normalitas, pengujian multikolinearitas, dan pengujian heteroskesdatisitas. Penelitian ini menggunakan analisis regresi berganda karena analisis ini dapat mengetahui arah hubungan antara variabel independen dengan variabel dependen (Ghozali, 2013). Terdapat persamaan statistik regresi berganda sebagai berikut :

$$
Y=\alpha+\beta_{1} X_{1}+\beta_{2} X_{2}+e
$$

(Robbins, 2013

Keterangan:

$\mathrm{Y}=$ Kepuasan kerja karyawan $\alpha=$ Konstanta

$\beta=$ Koefisien regresi

$X_{1}=$ Pengembangan karir $\quad X_{2}=$

Kompensasi $\mathrm{e}=$ Standar eror

\section{HASIL DAN PEMBAHASAN}

Berawal di akhir abad 19, bidang pabrik gula dan pabrik ketenagalistrikan di Indonesia mulai ditingkatkan saat beberapa perusahaan asal Belanda yang bergerak di bidang pabrik gula dan pabrik teh mendirikan pembangkit tenaga lisrik untuk keperluan sendiri. Pada 
tanggal 1 januari 1961, Jawatan Listrik dan Gas diubah menjadi BPU-PLN (Badan Pimimpin Umum Perusahaan Listrik Negara) yang bergerak di bidang listrik, gas dan kokas yang dibubarkan pada tanggal 1 Januari 1965. Pada saat yang sama, 2 (dua) perusahaan negara yaitu Perusahaan Listrik Negara (PLN) sebagai pengelola tenaga listrik milik negara dan Perusahaan Gas Negara (PGN) sebagai pengelola gas diresmikan. Pada tahun 1972, sesuai dengan Peraturan Pemerintah No. 17, status Perusahaan Listrik Negara (PLN) ditetapkan sebagai Perusahaan Umum Listrik Negara dan sebagai Pemegang Kuasa Usaha Ketenagalistrikan (PKUK) dengan tugas menyediakan tenaga listrik bagi kepentingan umum.

Seiring dengan kebijakan Pemerintah yang memberikan kesempatan kepada sektor swasta untuk bergerak dalam bisnis penyediaan listrik, maka sejak tahun 1994 status PLN beralih dari Perusahaan Umum menjadi Perusahaan Perseroan (Persero) dan juga sebagai PKUK dalam menyediakan listrik bagi kepentingan umum hingga sekarang.

PT PLN merupakan badan usaha milik negara yang bergerak dibidang pengelola tenaga listrik milik negara. Pusat dari PT PLN berlokasi di Jalan Trunojoyo Blok M - I No 135 Kebayoran Baru, Jakarta 12160, Indonesia. PT PLN juga memiliki kantor cabang diseluruh Indonesia dan salah satunya berada di Semarang. Kantor PLN Kota Semarang ini melayani kebutuhan listrik masyarakat seperti pengajuan pemasangan listrik, pengajuan naik tegangan atau tambah daya, cek tagihan listrik PLN, pembayaran listrik hingga komplain. Selain dari berkunjung ke PT PLN (Persero) Area Semarang, saat ini masyrakat sudah bisa melakukan cek rekening saldo listrik secara online, bayar listrik online dengan token listrik PLN, pembayaran online dapat dilakukan melalui ATM atau aplikasi mobile. Untuk info PLN lebih lanjut dapat diperoleh melalui website resmi PT PLN (Persero). Anda juga bisa berkunjung ke kantor PLN terdekat ini pada jam buka / kerja untuk mendapat bantuan langsung atau telepon call center PLN untuk informasi terkait lainnya.

Responden dalam penelitian ini adalah para karyawan pada PT PLN (Persero) UID Jateng \& DIY. Jumlah kuesioner yang disebar sebanyak 119 kuesioner. Rincian dari identitas responden dapat dilihat pada tabel 3 .

Tabel 4. Identitas Responden

\begin{tabular}{lccc}
\hline \multicolumn{2}{c}{ Kriteria Responden } & Jumlah Responden & Presentase Responden \\
\hline Jenis Kelamin & Laki-laki & 60 & $50,42 \%$ \\
\multirow{4}{*}{ Usia } & Perempuan & 59 & $49,58 \%$ \\
& $21-30$ & 23 & $19,3 \%$ \\
& $31-40$ & 52 & $43,7 \%$ \\
\multirow{4}{*}{ Tingkat Pendidikan } & 12 & $10,1 \%$ \\
& $41-50$ & 32 & $26,9 \%$ \\
& $>50$ & 11 & $9,2 \%$ \\
& SMA & 70 & $58,8 \%$ \\
& Strata 1 & 12 & $10,1 \%$ \\
& Strata 2 & 5 & $4,2 \%$ \\
& Diploma 1 & 21 & $17,6 \%$ \\
\hline
\end{tabular}

Sumber: Data primer diolah (2019)

Komposisi dari penyebaran responen pada PT PLN (Persero) UID Jateng \& DIY yaitu 50,42 persen dari responden berjenis kelamin laki-laki dan 49,58 persen berjenis kelamin perempuan. 119 dari responden tersebut seluruhnya merupakan karyawan dari PT PLN (Persero) UID Jateng \& DIY yang terdiri dari berbagai jabatan antara lain general manager, analyst, engineering, junior staff, manager, assistant manager. Jumlah responden terbanyak memiliki umur antara 3140 tahun dengan persentase sebesar 43,7 persen. Untuk tingkat pendidikan dari responden, 9,2 persen merupakan lulusan
SMA. 58,8 persen dari responden yang merupakan persentase terbesar adalah lulusan dari strata 1. 4,2 persen dan 17,6 persen dari responden merupakan lulusan diploma 1 dan diploma 3.

Analisis pengujian instrument pada penelitian ini meliputi uji validitas dan reliabilitas. Hasil dari pengujian ini dapat dijelaskan satu per satu sebagai berikut:

Menurut Ghozali (2013) uji validitas digunakan untuk mengukur sah atau valid tidaknya suatu kuesioner tersebut. Suatu kuesioner tersebut dikatakan valid jika pertanyaan yang terdapat pada kuesioner 
tersebut mampu mengungkapkan sesuatu yang akan diukur oleh kuesioner tersebut. Untuk mengetahui validitas dari kuesioner yang dibuat oleh peneliti, peneliti menggunakan cara melakukan korelasi antar skor butir pertanyaan dengan total variabel jika $r$ hitung lebih besar dari $r$ tabel dan bernilai positif maka indicator tersebutu valid (Ghozali, 2013). Bila harga korelasi dibawah 0,30 maka dapat disimpulkan pertanyaan dalam kuesioner tersebut tidak valid, sehingga harus diperbaiki atau dibuang.

Tabel 5. Uji Validitas Pengembangan Karir

\begin{tabular}{llll}
\hline Item & $\mathrm{R}$ Hitung & $\mathrm{R}$ Tabel & Keterangan \\
\hline $\mathrm{X} 1.1$ & & Valid \\
$\mathrm{X} 1.2$ & 0,422 & 0,361 & Valid \\
$\mathrm{X} 1.3$ & 0,501 & 0,361 & Valid \\
$\mathrm{X} 1.4$ & 0,649 & 0,361 & Valid \\
$\mathrm{X} 1.5$ & 0,504 & 0,361 & Valid \\
$\mathrm{X} 1.6$ & 0,834 & 0,361 & Valid \\
$\mathrm{X} 1.7$ & 0,622 & 0,361 & Valid \\
\hline
\end{tabular}

Tabel 5 menunjukkan variable pengembangan karir dengan keseluruhan dari kriteria valid untuk semua item pertanyaan
Sumber: Data diolah 2019 dengan nilai $r$ hitung yang lebih besar dari $r$ tabel dan positif maka butir pertanyaan atau indikator dinyatakan valid.

Tabel 6. Uji Validitas Kompensasi

\begin{tabular}{llll}
\hline Item & R Hitung & R Tabel & Keterangan \\
\hline X1.1 & 0,655 & 0,361 & Valid \\
X1.2 & 0,703 & 0,361 & Valid \\
X1.3 & 0,784 & 0,361 & Valid \\
X1.4 & 0,493 & 0,361 & Valid \\
X1.5 & 0,683 & 0,361 & Valid \\
X1.6 & 0,733 & 0,361 & Valid \\
X1.7 & 0,742 & 0,361 & Valid \\
\hline
\end{tabular}

Sumber: Data diolah

Tabel 7. Uji Validitas Kepuasan Kerja

\begin{tabular}{llll}
\hline Item & R Hitung & R Tabel & Keterangan \\
\hline Y1.1 & 0,662 & 0,361 & Valid \\
Y.1.2 & 0,720 & 0,361 & Valid \\
Y1.3 & 0,671 & 0,361 & Valid \\
Y1.4 & 0,421 & 0,361 & Valid \\
Y1.5 & 0,680 & 0,361 & Valid \\
Y1.6 & 0,403 & 0,361 & Valid \\
Y1.7 & 0,496 & 0,361 & Valid \\
\hline
\end{tabular}

Tabel 10 menunjukkan variabel kepuasan kerja dengan keseluruhan dari kriteria valid untuk semua item pertanyaan dengan nilai $r$ hitung yang lebih besar dari $r$ tabel dan positif maka butir pertanyaan atau indikator dinyatakan valid.

Uji reliabilitas digunakan untuk menguji konsistensi jawaban dari pertanyaan yang diajukan dalam kuesioner penelitian dari satu responden dengan responden lainnya. Kuesioner dikatakan reliabel atau handal ketika jawaban terhadap pernyataan adalah konsisten atau sama dari waktu ke waktu (Ghozali, 2013). Suatu konstruk atau variabel dikatakan reliabel jika memberikan nilai Cronbach alpha > 0,60. Selain itu, untuk menganalisa inner model dapat dilihat melalui nilai $R$-Square. Suatu konstruk atau variabel 
dikatakan reliabel jika memberikan nilai Cronbach Alpha lebih besar dari 0,6 dan nilai Composite Reliability lebih dari atau sama dengan 0,70. Tabel 11 dibawah ini menunjukkan hasil dari pengujian reliabilitas.

Tabel 8. Uji Realibilitas

\begin{tabular}{cll}
\hline Cronbachs Alpha & Pengukuran Reliabilitas & \\
\hline 0,822 & Cronbachs Alpha $>0,60$ & Reliabel \\
\hline
\end{tabular}

Sumber : Data Primer Diolah (2019)

Statistik deskriptif memberikan gambaran atau deskripsi suatu data yang dilihat dari nilai minimum, maksimum, rata-rata (mean), dan standar deviasi. Pada sub ini akan dibahas tentang tanggapan responden tentang pengembangan karir, kompensasi, dan kepuasan kerja berdasarkan rekap jawaban responden penelitian.

Tabel 9. Statistik Deskriptif Konstruk

\begin{tabular}{lccccc}
\hline \multicolumn{1}{c}{ Konstruk } & $\mathrm{N}$ & Min & Maks & Rata-rata & Std. Deviasi \\
\hline Pengembangan Karir & 119 & 16 & 35 & 28,9748 & 2,8320 \\
Kompensasi & 119 & 25 & 35 & 29,7479 & 2,61099 \\
Kepuasan Kerja & 119 & 19 & 35 & 28,5042 & 2,72115 \\
\hline
\end{tabular}

Tabel diatas menunjukkan bahwa dari

Data diatas menunjukkan jumlah dari responden $(\mathrm{N})$ 119, dari 119 responden nila dari variabel pengembangan karir yang didapat dari penjumlahan nilai dari keseluruhan pertanyaan pada variabel tersebut menunjukkan bahwa nilai terkecil (minimum) adalah 16 dan nilai tertinggi (maksimal) pada pengembangan karir adalah 35. Rata-rata dari keseluruhan nilai pada variabel pengembangan karir adalah 28,9748 dengan standar deviasinya sebesar 2,8320.
119 responden, nilai dari variabel kompensasi yang didapat dari penjumlahan nilai dari keseluruhan pertanyaan pada variabel tersebut menunjukkan bahwa nilai terkecil (minimum) adalah 25 dan nilai tertinggi (maksimal) pada kompensasi adalah 35. Ratarata dari keseluruhan nilai pada variabel kompensasi adalah 29,7479 dengan standar deviasinya sebesar 2,61099 .

Tabel 10. Rekap Tanggapan Responden Tentang Pengembangan Karir

\begin{tabular}{|c|c|c|c|c|c|c|c|}
\hline No & Pertanyaan & STS & TS & $\mathrm{RR}$ & $S$ & SS & Mean \\
\hline 1 & $\begin{array}{l}\text { Latar belakang pendidikan yang saya miliki } \\
\text { dapat untuk mengembangkan karir kerja saya di } \\
\text { PT PLN (Persero) UID Jateng \& DIY. }\end{array}$ & 0 & 9 & 8 & 70 & 32 & 4,05 \\
\hline 2 & $\begin{array}{l}\text { Saya memiliki pengetahuan yang cukup untuk } \\
\text { melaksanakan pekerjaan saya. }\end{array}$ & 1 & 1 & 2 & 91 & 24 & 4,14 \\
\hline 3 & $\begin{array}{l}\text { Perusahaan selalu memberikan pelatihan- } \\
\text { pelatiha rutin kepada karyawannya. }\end{array}$ & 1 & 3 & 0 & 99 & 16 & 4,05 \\
\hline 4 & $\begin{array}{l}\text { Pelatihan yang diberikan perusahaan membuat } \\
\text { saya mendapat keahlian tertentu yang dapat } \\
\text { membantu dalam bekerja. }\end{array}$ & 1 & 0 & 1 & 93 & 24 & 4,16 \\
\hline 5 & $\begin{array}{l}\text { Saya memiliki pengalaman kerja yang } \\
\text { mencukupi untuk menjalankan pekerjaan ini. }\end{array}$ & 2 & 1 & 3 & 79 & 34 & 4,19 \\
\hline 6 & $\begin{array}{l}\text { Saya memiliki penguasaan pengetahuan yang } \\
\text { luas untuk pengembangan karir dan profesi } \\
\text { saya. }\end{array}$ & 0 & 2 & 2 & 87 & 28 & 4,18 \\
\hline 7 & $\begin{array}{l}\text { Saya memiliki keterampilan yang dapat } \\
\text { menunjang karir saya dalam bekerja. }\end{array}$ & 0 & 2 & 1 & 90 & 26 & 4,17 \\
\hline & Mesn Total & & & & & & 4,13 \\
\hline
\end{tabular}


Tabel 11. Rekap Tanggapan Responden Tentang Kompensasi

\begin{tabular}{|c|c|c|c|c|c|c|c|}
\hline No & Pertanyaan & STS & TS & $\mathrm{RR}$ & $S$ & SS & Mean \\
\hline 1 & $\begin{array}{l}\text { Saya menerima gaji yang dapat memenuhi } \\
\text { kebutuhan hidup sehari-hari. }\end{array}$ & 0 & 0 & 6 & 77 & 36 & 4.25 \\
\hline 2 & $\begin{array}{l}\text { Jumlah gaji yang saya terima dapat } \\
\text { meningkatkan semangat kerja. }\end{array}$ & 0 & 3 & 2 & 80 & 24 & 4.22 \\
\hline 3 & $\begin{array}{l}\text { Jumlah gaji yang saya terima sesuai dengan } \\
\text { ketentuan yang sudah ditetapkan. }\end{array}$ & 0 & 1 & 4 & 81 & 33 & 4.23 \\
\hline 4 & $\begin{array}{l}\text { Perusahaan biasanya memberikan insentif } \\
\text { kepada karyawan untuk meingkatkan kinerja } \\
\text { karyawan. }\end{array}$ & 0 & 0 & 4 & 76 & 39 & 4.30 \\
\hline 5 & $\begin{array}{l}\text { Saya selalu mendapatkan tunjangan secara } \\
\text { rutin dari perusahaan. }\end{array}$ & 0 & 1 & 1 & 83 & 34 & 4.26 \\
\hline 6 & $\begin{array}{l}\text { Perusahaan telah memberikan tunjangan } \\
\text { sesuai aturan yang berlaku. }\end{array}$ & 0 & 0 & 5 & 82 & 32 & 4.23 \\
\hline 7 & $\begin{array}{c}\text { Perusahaan memberikan tunjangan guna } \\
\text { meingkatkan semangat kerja karyawannya. } \\
\text { Mean Total }\end{array}$ & 0 & 1 & 3 & 78 & 37 & 4.27 \\
\hline
\end{tabular}

Sumber: Data Primer Di Olah, 2019

Pada penelitian ini pengujian dilakukan dengagn menggunakan teknik analisis linier berganda. Tujuan dari analisis regresi linear berganda untuk mengetahui apakah variabel
1 independen berhubungan positif ataukah negatif terhadap variabel dependen. Tabel 12 dibawah ini menunjukkan hasil dari pengujian regresi berganda.

Tabel 12. Pengaruh Total

\begin{tabular}{lccc}
\hline Variabel & Coeficient (B) & Sig & Keterangan \\
\hline Pengembangan Karir & 0.424 & 0.000 & Diterima \\
Kompensasi & 0.490 & 0.000 & Diterima \\
\hline
\end{tabular}

Berdasarkan tabel 15 di atas dapat dijelaskan persamaan 1 regresi linier berganda sebagai berikut: $Y 1=1,668+0,424 X 1+$ $0,490 X 2$. Berdasarkan persamaan tersebut menjelaskan besarnya nilai koefisien regresi untuk variabel pengembangan $\operatorname{karir}\left(\mathrm{x}_{1}\right)=$ $+0,424$, dan Kompensasi $\left(x_{2}\right)=+0,490$, sehingga koefisien regresi variabel kompensasi lebih besar dari pada koefisien regresi variabel pengembangan karir. Berarti kompensasi memiliki pengaruh yang lebih besar terhadap kepuasan kerja(Y1).

Hasil pengujian memperoleh bukti empiris bahwa hipotesis $1 \quad\left(H_{1}\right)$ diterima dengan koefisien positif. $\mathrm{Hal}$ ini berarti pengembangan karir memilki pengaruh signifikan terhadap kepuasan kerja para karyawan di PT PLN (Persero) UID Jateng \& DIY. Dari penelitian ini dapat diketahui pada implikasinya ketika para karyawan PT PLN (Persero) UID Jateng \& DIY memiliki karir yang terus berkembang dalam artian karir dalam pekerjaan terus meningkat ternyata hal tersebut membuat para karyawan merasa puas atas pencapaian atau pekerjaan yang dilakukan. Jadi kenaikan jabatan menjadi suatu ukuran para karyawan PT PLN (Persero) UID Jateng \& DIY untuk merasakan kepuasan Data diatas menunjukkan jumlah dari responden $(\mathrm{N})$ 119, dari 119 responden nilai kerja pada diri mereka. Hasil penelitian ini konsisten dengan penelitian yang dilakukan oleh Nugroho \& Kunartinah (2012) dan Kurniawan (2015) yang menyatakan bahwa pengembangan karir memiliki pengaruh positif dan signifikan terhadap kepuasan kerja pada para karyawan di Sekertariat daerah Kabupaten Pekalongan.

Hipotesis $2\left(\mathrm{H}_{2}\right)$ juga diterima dengan koefisien positif. Hal ini menunjukkan bahwa semakin tinggi, besar, dan sering kompensasi yang diberikan untuk para karyawan pada PT PLN (Persero) UID Jateng \& DIY maka akan semain tinggi pula tingkat kepuasan para karyawan dalam bekerja. Dari penelitian ini dapat diketahui bahwa kompensasi merupakan hal yang sangat penting bagi karyawan dalam saran untuk memenuhi kebutuhan sehari-hari maupun bersama keluarganya. Kompensasi yang diberikan oleh 
perusahaan kepada karyawan juga menjadi ukuran untuk menilai kepuasan kerja yang dirasakan oleh para karyawan. Mengacu pada penelitian sebelumnya yang dilakukan oleh Nugroho dan Kunartinah (2012) yang menyatakan bahwa kompensasi memiliki pengaruh positif dan signifikan terhadap kepuasan kerja pada para karyawan di Sekertariat daerah Kabupaten Pekalongan, hal ini juga dibuktikan oleh penelitian ini yang juga memperoleh hasil bahwa kompensasi berpengaruh positif dan signifikan terhadap kepuasan kerja. Hal ini juga didukung oleh penelitian yang dilakukan Kurniawan (2015) menyatakan bahwa kompensasi memiliki pengaruh yang signifikan dan positif terhadap kepuasan dalam bekerja.

\section{PENUTUP}

Hasil penelitian ini membuktikan secara empiris pengembangan karir berpengaruh positif terhadap kepuasan kerja para karyawan PT PLN (Persero) UID Jateng \& DIY, dibuktikan nilai $p$-value $(0,000)>\operatorname{sig}(0,05)$. Hal ini berarti dengan meningkatkan pengembangan karir karyawan PT PLN (Persero) UID Jateng \& DIY, karyawan tersebut akan memiliki kepuasan kerja yang cukup tinggi. Penelitian juga membuktikan bahwa kompensasi berpengaruh positif terhadap kepuasan kerja para karyawan di PT PLN (Persero) UID Jateng \& DIY,dibuktikan nilai $p$-value $(0,000)<\operatorname{sig}(0,05)$. Hal ini berarti dengan meningkatkan kompensasi karyawan pada PT PLN (Persero) UID Jateng \& DIY maka karyawan tersebut akan memiliki kepuasan kerja yang cukup tinggi.

Bagi peneliti selanjutnya, diharapkan perlu menambahkan variabel-variabel lain dalam menilai kepuasan kerja pada karyawan dengan mengikutkan faktor-faktor, seperti: resiko pekerjaan, rekan kerja, dukungan penyelia, keamanan bekerja, dan perilaku pimpinan. Sebab faktor-faktor tersebut juga disinyalir menjadi penyebab timbulnya kepuasan kerja. Penelitian selanjutnya diharapkan melakukan pengujian dengan metode yang berbeda dari penelitian-penelitian sebelumnya. Hal ini diharapkan dapat agar menghasilkan jawaban yang lebih spesifik dan beragam dalam menilai kepuasan kerja seperti halnya menggunakan metode wawancara untuk memperoleh hasil yang lebih mendalam selain hanya dengan menggunakan metode kuesioner.

\section{DAFTAR PUSTKA}

Akhyadi, \& Sadikin, A. (2015). Pengembangan Sumber Daya Manusia. Bandung: Alfabeta.

Akmal, A., \& Tamini, I. (2015). Pengaruh Kompensasi Terhadap Kepuasan Kerja Karyawan Gaya Makmur Mobil Medan. Jurnal Bisnis Administrasi: 4(2): $59-68$

Alif, A. (2015). Pengaruh Motivasi Kerja, Pengembangan Karir dan Lingkungan Kerja Terhadap Organizational Citizenship Behavior (OCB) dengan Kepuasan Kerja Sebagai Variabel Intervening Pada Perusahaan Terminal LPG. Jurnal MIX Vol.6: 291309.

Damayanti, R., Hanafi, A., \& Cahyadi, A. (2018). Pengaruh Keputusan Kerja Terhadap Kinerja Karyawan. Jurnal IImiah Manajemen Bisnis Dan Terapan: 75-86.

Dessler, G. (2006). Manajemen Sumber Daya Manusia, Jilid 1. Klaten: PT. Indeks.

Fauzi, U. (2014). Pengaruh Kompensasi Terhadap Kinerja Karyawan . Jurnal IImu Administrasi Bisnis: 1-14.

Firmandari, N. (2014). Pengaruh Kompensasi Terhadap Kinerja Karyawan Dengan Motivasi Sebagai Variabel Moderasi. Jurnal Ekonomi Dan Bisnis Islam: 2534.

Handoko, T. (2008). Manajemen Personalia dan Sumber Daya Manusia. Yogyakarta: BPEE.

Handoko. (2012). Manajemen Personalia dan Sumber Daya Manusia. Yogyakarta: BPEE.

Hasibuan, \& Melayu, S. P. (2001). Manajemen Sumber Daya Manusia. Jakarta: Edisi Revisi Bumi Aksara.

Hasibuan. (2006). Manajemen Sumber Daya Manusia. Jakarta: Edisi Revisi Bumi Aksara.

Hasibuan. (2012). Manajemen Sumber Daya Manusia. Edisi Revisi. Jakarta: PT. Bumi Aksara . 
Humaeroh, Susilo, H., \& Prasetya, A. (2015). Pengaruh Kompensasi Terhadap Kepuasan Kerja Karyawan Dan Dampaknya Terhadap Motivasi Kerja Pada Karyawan PT. Krakatau Steel. Jurnal Administrasi Bisnis Volume 27 (2): 1-8.

Kurniawan, (2015). Pengaruh Pengembangan Karir Dan Kompensasi Terhadap Kepuasan Kerja Karyawan Di PT. Parit Padang Global. Jurnal Manajemen Bisnis Universitas Kristen Petra Agora Volume: 1-10.

Lisdiani, V. (2017). Pengaruh Pengembangan Karir Terhadap Kepuasan Kerja Karyawan Melalui Motivasi Sebagai Variabel Intervening Studi Pada Hotel Grasia Semarang. Diponegoro Journal of Social and Political Science: 1-8.

Luthans, F. (2006). Perilaku Organisasi Edisi Sepuluh. Yogyakarta: PT. Andi.

Marfokah, \& Tri, R. (2015). Pengaruh Kompensasi Dan Pengembangan Karir Terhadap Kinerja Karyawan PT. Nasmoco Magelang. Diponegoro University Journal Of Social And Politic: 1-15.

Massie, R., Tewal, B., \& Sendow, G. (2015). Pengaruh Perencanaan Karir, Pelatihan Dan Pengembangan Karir Terhadap Kinerja Pegawai. Jurnal Berkala Ilmiah Efisiensi: 536-545.

Muchlis. (2017). Pengaruh Pengembangan Karir, Penempatan Motivasi Dan Lingkungan Kerja Terhadap Kinerja Pegawai Dan Dampaknya Pada Kinerja Dinas Pendidikan Aceh. Jurnal Manajemen Dan Inovasi: 1-12.

Mulayani, N. (2002). Tantangan Perusahaan Di Indonesia Dalam Menghadapi Persaingan Global. Jurnal Widya Manajemen Dan Akuntansi: 255-269.

Noe, R. M., \& Mondy, R. W. (2005). Human Resource Management Ninth Edition USA: Prentice Hall.

Nugroho, A. D., \& Kunartinah. (2012). Analisis Pengaruh Kompensasi dan Pengembangan Karier Terhadap Kepuasan Kerja Dengan Mediasi Motivasi. Jurnal Bisnis dan Ekonomi Vol.19(2): 1-10.
Paramita, W., Wahda, L. A., \& Handaru, A. W. (2015). Pengaruh Pengembangan Karir Dan Motivasi Terhadap Kepuasan Kerja Karyawan PT. Pos Indonesia (Persero) Bekasi. Jurnal Riset Manajemen Sains Indonesia VIo.6: 326-351.

Permatasari, I. R. (2006). Pengaruh Pengembangan Karir Terhadap Kinerja Karyawan . Jurnal Ekonomi Modernisasi: 1-13.

Priyatno, D. (2013). Mandiri Belajar Analisis Data Dengan SPSS. Yogyakarta: Mediakom.

Putra, S. D., Musnadi, S., \& Majid, M. S. (2014). Pengaruh Budaya Organisasi, Kompensasi Dan Pengembangan Karir Terhadap Kepuasan Kerja Perawat Serta Dampaknya Terhadap Kinerja Perawat Badan Layanan Umum Daerah Rumah Sakit Jiwa Aceh . Jurnal Manajemen Pascasarjana Universitas Syiah Kuala Vol.3: 85-93.

Retnoningsih, T., Sunuharjo, B. S., \& Ruhana, I. (2016). Pengaruh Kompensasi Terhadap Kepuasan Kerja dan Kinerja Karyawan . Jurnal Administrasi Bisnis: 35(2): 53-59.

Reventiary, A., \& Pradana. (2016). Pengaruh Atribut Produk Terhadap Keputusan Pembelian Sepatu Merek Customade (Studi Pada Merek Dagang Customade Indonesia). Jurnal Manajemen: 1-10.

Robbins, S. P. (2013). Organizational Behavior Edition 15. New Jersey: Pearson Education.

Sari, O. R., \& Susilo, H. (2018). Pegaruh Kepuasan Kerja Terhadap Kinerja Karyawan dengan Organization Citizhenship Behavior. Jurnal Administrasi Bisnis: 28-35.

Siswadhi, F. (2017). Pengaruh Pengembangan Karir dan Kepemimpinan Terhadap Kepuasan Kerja Pegawai Pada Badan Pelaksana Penyuluhan dan Ketahanan Pangan Kota Sungai Penuh. Jurnal Benefita: 72-80. 
Sugiharjo, R. J., \& Rustinah. (2017). Pengaruh Perencanaan Karir, Pengembangan Karir Karyawan Dan Kompensasi Terhadap Kinerja Karyawan. Jurnal IImiah Manajemen Dan Bisnis: 444454.

Sugiyono. (2013). Metode Penelitian Kuantitatif Kualitatif Dan $R \& D$. Bandung: Alfabeta.

Sugiyono (2014). Metode Penelitian Pendidikan Pendekatan Kuantitatif, Kualitatif, dan R\&D. Bandung: Alfabeta.

Sunyoto, D. (2012). Manajemen Sumber Daya Manusia, Cetakan 1. Yogyakarta: CAPS.

Supatmi, M. E., Nimran, U., \& Utami, H. N. (2011). Pengaruh Pelatihan, Kompensasi Terhadap Kepuasan Kerja Karyawan Dan Kinerja Karyawan. Jurnal Profit Vol.7: 25-37.

Suwanto, H., \& Priansa, J. D. (2011). Manajemen Sumber Daya Manusia Dalam Organisasi Publik dan Bisnis. Bandung: Alfabeta.

Utama, A., \& Edy. (2013). Pengaruh Kompensasi, Gaya Kepemimpinan Dan Pengembangan Karir Terhadap Kepuasan Kerja Karyawan pada karyawan produksi UAP LEAN PT Techpack Asia. Q-MAN, Vol 2(1): 115. 